\title{
Comparative effect of mixture of ginger and honey with dextromethorphan in dry cough in children
}

\author{
Deepali L. Jaybhaye ${ }^{1 *}$, Shruti Chandra ${ }^{1}$, Sukhmeen Johar ${ }^{1}$, Abhijit S. Nagre ${ }^{2}$
}

${ }^{1}$ Department of Pharmacology, MGM Medical College, Aurangabad, Maharashtra, India
${ }^{2}$ MBBS student, Topiwala National Medical College, Mumbai, Maharashtra, India

Received: 10 March 2021

Revised: 10 April 2021

Accepted: 12 April 2021

*Correspondence:

Dr. Deepali L. Jaybhaye,

Email: deepalijaybhaye@ rediffmail.com

Copyright: (c) the author(s), publisher and licensee Medip Academy. This is an open-access article distributed under the terms of the Creative Commons Attribution Non-Commercial License, which permits unrestricted non-commercial use, distribution, and reproduction in any medium, provided the original work is properly cited.

\begin{abstract}
Background: Cough is protective reflex caused by obstruction or irritation of airway. Many medication available for the treatment of dry cough. But it causes sedation and drowsiness in children. Considering the adverse effects produce by the medication, we consider this study as the ginger and honey is used in Indian family, and in Ayurveda ginger and honey is used for treatment of dry and productive cough.

Methods: We include the patients who attended the pediatric OPD complaining dry cough. We design the questionnaire and for the measuring the severity of dry cough. We divide the patient into four groups received standard treatment and ginger and honey mixture. We compared the end result with standard treatment statistically by using unpaired student " $t$ " test was used along with two-way analysis of variance (ANOVA) test.

Results: We include 100 patient in this study. We got amazing result of this study ginger and honey required less time for recovery and also sedation and drowsiness not occurred in the ginger and honey group as compared to dextromethorphan ( $p$ value $<0.005$ ).

Conclusions: After seeing above encouraging result, and along with advantage of natural product with no adverse we can advise the honey and ginger therapy for treatment of dry cough.
\end{abstract}

Keywords: Dry cough, Honey and ginger, Dextromethorphan

\section{INTRODUCTION}

Cough is protective reflex triggered by obstruction of airway along with irritation of airway. For the clearance of airway by cough and escalator. ${ }^{1}$ Cough is one common symptom in clinical practice, whereas a persistent cough is one of the most common clinical problems for which the patient referred to pediatrician, pulmonary physicians, and otolaryngologists. ${ }^{2}$ Cough is a physiological reflex present with violent expiration to remove the secretions and foreign bodies, overcome bronchospasm, and protect the respiratory system. ${ }^{2}$ The receptors for the cough are present in the bronchi which is stimulated by chemical irritation, mechanical stimulation, and tactile stimulation. Cough having afferent pathway through branches of the vagus nerve and laryngeal nerves to the brainstem and the impulse modulated at the cerebral cortex followed by the efferent motor pathway goes to respiratory muscles. Upper respiratory tract infections (URTIs), bronchial asthma, gastroesophageal reflux disease, bronchial hyperactivity and angiotensin-converting enzyme (ACE) inhibitor treatment cause increase sensitivity of the cough receptors. $^{3}$

Most of the children use one or more products in a given week. Over-the counter (OTC) products, mostly cough and cold medications, account for most medication exposures. ${ }^{4}$ Cough and cold medications including antitussives, expectorants, antihistamines, decongestants, and antipyretics such as acetaminophen. ${ }^{5,6}$ 
For the treatment of dry cough we use dextromethorphan and with antihistaminic pharyngeal demulcents. But most of the drug has adverse effects like, decongestants have been linked to cardiac arrhythmias, antihistamines to hallucinations, and antitussives to depressed levels of consciousness and encephalopathy. ${ }^{7}$ Hospital episode statistics in foreign countries like England 2006/7 showed 230 children under 14 were admitted to hospital as a consequence of exposure to antitussives, expectorants or common cold remedies (11 poisoning by antitussives, 39 poisoning by expectorants, 182 poisoning by common cold remedies). ${ }^{8}$ The USA the food and drug administration identified 123 deaths related to cough remedies. ${ }^{7}$ The medicines and healthcare products regulatory agency (MHRA) now advises children less than 6 years old should not be treated with over the counter cough and cold medication. ${ }^{8}$ Most of physician advised that children suffering from cough should be treated with a simple cough syrup (such as glycerol, honey or lemon). ${ }^{10}$

In Ayurveda honey and ginger is main stay treatment of cough dry as well as productive cough. And now World Health Organization (WHO) also regards honey as a potentially valuable demulcent for the treatment of cough. ${ }^{11}$ Ginger (Z. officinale rhizome) is an all-round treatment for prevention and treatment of cough, common cold and flu like symptoms through immune enhancement. ${ }^{12}$ Ginger has antimicrobial activity against Bacillus spp. and Staphylococcus aureus. ${ }^{13}$ Honey is a sweet viscous liquid with a complex composition of carbohydrates, free amino acids, vitamins, trace elements and flavonoids and also acts as antioxidants. Honey process anti-bacterial, antiviral and anti-inflammatory properties. ${ }^{14,15}$ Studies of the antimicrobial effect of honey have demonstrated its broad-spectrum antimicrobial actions against various gram-positive and gram-negative bacteria including bacterial found in the upper respiratory tract such as Staphylococcus aureus and Streptococcus faecalis. Eccles in review, argues that the sweetness of liquid preparations used to treat cough accounts for much of the observed effect. ${ }^{16}$ Eccles said sweet substances naturally cause reflex salivation and production of airway mucus leading to a demulcent effect on the pharynx and larynx, and reducing cough. There is interaction between opioid-responsive sensory fibers and the gustatory nerves to help produce an antitussive effect via the central nervous system. ${ }^{16}$

So, we consider this study to see the efficacy and safety of honey and ginger mixture in comparison with dextromethorphan in dry cough.

\section{METHODS}

The study was approved by institutional ethics Committee, MGM Medical College, Aurangabad.

Paediatric patients who attended paediatric outpatient department (OPD) from January 2017 to March 2017 were included in this study. Patients were those between the age of 1 to 17 years complaining of dry cough along with upper respiratory tract infection. Upper respiratory infection means presence of cough and rhinorrhea of seven days duration with or without nasal congestion and fever, sore throat, myalgia, and headache. While we excluded if patients were had productive cough, signs or symptoms of asthma, pneumonia, laryngotracheobronchitis, sinusitis, and/or allergic rhinitis, along with it we also excluded the patients receiving any cough or cold medication or honey on the night before entering the study.

\section{Pre-intervention study questionnaire}

After getting informed consent from parents, all participating parents of children were asked to complete a questionnaire regarding their subjective assessments of the child's cough and sleep difficulty on the previous night. The questionnaire used was a Hebrew version of a previously validated questionnaire (Figure 1). ${ }^{17}$ Survey responses were graded on a 7-point Likert scale. Minimum symptom severity score criteria were established to determine which children should enter the randomized trial. Only children whose parents rated a severity of at least 3 for a minimum of 2 of the 3 questions related to nocturnal cough frequency, effect on the child's sleep, and effect on parental sleep on the previous night were included: how frequently your child is coughing last day?, what is the severity of cough last day?, how bothersome was last night's cough to your child?, how much did last night's cough affect your child ability to sleep?, and how much did last night cough disturb parent sleep?

Cough severity and adverse effect assessment questionnaire - 0-not at all, 1-not much, 2-a little, 3somewhat, 4-a lot, 5-very much, 6-extremely and 7-severe.

\section{Study design}

This is open label study. The patients included in this study were divided in to 4 treatment groups as given below.

Group I consists of syrup/tablet amoxicillin and clavulanic acid (15 mg/kg twice daily) (tablet clavam) and tablet montelukast and levocetirizine (4/1.25 mg OD upto 5 years age and 5-10/2.5-5 $\mathrm{mg}$ OD above 5 years age) \pm syrup/tablet paracetamol (15 mg/kg SOS).

Group II consists of syrup/tablet amoxicillin and clavulanic acid (15 mg/kg twice daily) (tablet clavam) and syrup dextromethorphan-100 mg/5 ml with triprolidine$1.25 \mathrm{mg} / 5 \mathrm{ml}$ (syrup ascoril D) four times a day and tablet montelukast and levocetirizine (4/1.25 mg OD upto 5 years age and 5-10/2.5-5 $\mathrm{mg}$ OD above 5 years age \pm syrup/tablet paracetamol (15 mg/kg SOS).

Group III consists of syrup/tablet amoxicillin and clavulanic acid (15 mg/kg twice daily) (tablet clavam) and syrup dextromethorphan-100 $\mathrm{mg} / 5 \mathrm{ml}$ with triprolidine$1.25 \mathrm{mg} / 5 \mathrm{ml}$ (syrup ascoril D) four times a day and tablet montelukast and levocetirizine $(4 / 1.25 \mathrm{mg}$ OD upto 5 
years age and 5-10/2.5-5 $\mathrm{mg}$ OD above 5 years age \pm syrup/tablet paracetamol $(15 \mathrm{mg} / \mathrm{kg} \mathrm{SOS})$ and honey 2.5-5 ml (6 month to 5 years-above 5 years ) along with 1 $\mathrm{ml}$ of ginger juice (6 month to 5 years-above 5 years).

Group IV consists of syrup/tablet amoxicillin and clavulanic acid ( $15 \mathrm{mg} / \mathrm{kg}$ twice daily) (tablet clavam) and tablet montelukast and levocetirizine (4/1.25 mg OD upto 5 years age and 5-10/2.5-5 mg OD above 5 years age \pm syrup/tablet paracetamol $(15 \mathrm{mg} / \mathrm{kg} \mathrm{SOS})$ and honey 2.5-5 ml (6 month to 5 years- above 5 years) along with 1 $\mathrm{ml}$ of ginger juice (6 month to 5 years- above 5 years).

\section{Honey and ginger mixture preparation}

We ask parents of patient to buy honey from market (Dabur honey) and ginger purchased from local market. We advise parents mix the honey $2.5-5 \mathrm{ml}$ (6 month to 5 years- above 5 years) along with $1 \mathrm{ml}$ of ginger juice. Ginger juice was prepared by grinding it. This mixture given to children 4 times a day.

We include total 105 patients after obtaining the informed consent from parents and, this study was OPD base, we interviewed the parents after attaining the OPD till 10 days daily and asked the below question verbally on mobile phone. Out of 105 patient 5 were drop out due to mobile phone problem.

\section{Post-intervention study questionnaire}

After starting treatment, the day after the treatment, the patient who completed pretreatment questionnaire in pediatrics OPD, we took mobile number of those parents and post intervention questionnaire was contacted by telephone using mobile numbers. We asked the parent the same 5 questions that had been answered in writing before the intervention, this time regarding the previous evening when the child had received the treatment. No physician examination was performed on the second study day unless dictated by illness progression.

We also include the post-questionnaire to see the improvement and to monitor the adverse effect (ADR). We included five more questions in previous questionnaire: how frequently your child is coughing last day?, what is the severity of cough last day?, how bothersome was last night's cough to your child?, how much did last night's cough affect your child ability to sleep?, how much did last night cough disturb parent sleep?, any unwanted effect occur during taking medication?, any hangover effect experience?, any sedation experience?, vomiting? and drowsiness? Cough severity and adverse effect assessment questionnaire - 0-not at all, 1-not much, 2-a little, 3somewhat, 4-a lot, 5-very much, 6-extremely, and 7severe.

\section{Outcome measures}

The primary outcome was how much improvement in cough in day time and how many time there was awaking of child. It is measure by the improvement in symptoms. Secondary outcome measure by improvement in bothersome nature of the cough, the effect of the cough on sleep for both the child and the parent. We also note the occurrence of adverse effects.

\section{Statistical analysis}

Statistical analysis performed by using Statistical comparisons of variables between treatment groups. We used a unpaired Student ' $t$ ' test was used along with two way analysis of variance (ANOVA) test, and p value less than 0.05 was considered statistically significant. All statistical analyses were done by using the statistical package for the social sciences (SPSS) software.

\section{RESULTS}

105 children enrolled in the study out of this 100 completed the study. Five excluded from study due to diversion of treatment or their mobile was switch off. The baseline score of all four groups including cough frequency, severity, bothersome nature of cough, sleep quality in children and parents shown in Table 1. As shown in table there in no significant difference in baseline score in all groups. After the treatment of all cough related aspect was significantly decreased (Table 2). The comparison mean difference in the pre- and post-treatment scores of the groups is shown in Table 3. The mean differences between cough related aspects were significantly different between the three groups except for cough severity. Where $\mathrm{p}$ value is highly significant. Along with it we also monitored adverse effects of drugs. In our study most of the adverse effects (hangover, sedation, vomiting, drowsiness) our in the group II and III while only one patient in group one suffered from vomiting (Table 4).

At the end we also calculate the average time required for the full recovery, and it is less in group III. In group III only 4.5 days required for recovery (Table 5). No one participants was deteriorated during study.

Table 1: Baseline scores of the four groups.

\begin{tabular}{|c|c|c|c|c|c|c|c|c|}
\hline \multirow[b]{2}{*}{ Item } & \multicolumn{4}{|c|}{ Treatment group } & \multicolumn{4}{|c|}{ Mean difference } \\
\hline & $\begin{array}{l}\text { Group } \\
\text { I }\end{array}$ & Group II & $\begin{array}{l}\text { Group } \\
\text { III }\end{array}$ & $\begin{array}{l}\text { Group } \\
\text { IV }\end{array}$ & $\begin{array}{l}\text { G1 } \\
\text { versus } \\
\text { G2 }\end{array}$ & $\begin{array}{l}\text { G1 } \\
\text { versus } \\
\text { G3 }\end{array}$ & $\begin{array}{l}\text { G1 } \\
\text { versus } \\
\text { G4 }\end{array}$ & $\begin{array}{l}\text { G3 } \\
\text { versus } \\
\text { G4 }\end{array}$ \\
\hline Cough frequency & $3.5 \pm 0.3$ & $3.6 \pm 0.2$ & $3.5 \pm 0.3$ & $3.7 \pm 0.1$ & -0.1 & 00 & 0.2 & -0.2 \\
\hline Cough severity & $3.7 \pm 0.2$ & $4.5 \pm 0.2$ & $3.7 \pm 0.4$ & $3.6 \pm 0.2$ & -0.8 & 00 & -0.1 & 0.1 \\
\hline
\end{tabular}




\begin{tabular}{|c|c|c|c|c|c|c|c|c|}
\hline \multirow[b]{2}{*}{ Item } & \multicolumn{4}{|c|}{ Treatment group } & \multicolumn{4}{|c|}{ Mean difference } \\
\hline & $\begin{array}{l}\text { Group } \\
\text { I }\end{array}$ & Group II & $\begin{array}{l}\text { Group } \\
\text { III }\end{array}$ & $\begin{array}{l}\text { Group } \\
\text { IV }\end{array}$ & $\begin{array}{l}\text { G1 } \\
\text { versus } \\
\text { G2 }\end{array}$ & $\begin{array}{l}\text { G1 } \\
\text { versus } \\
\text { G3 }\end{array}$ & $\begin{array}{l}\text { G1 } \\
\text { versus } \\
\text { G4 }\end{array}$ & $\begin{array}{l}\text { G3 } \\
\text { versus } \\
\text { G4 }\end{array}$ \\
\hline Bothersome nature of cough & $3.5 \pm 0.3$ & $3.6 \pm 1.2$ & $3.4 \pm 1.5$ & $2.9 \pm 0.2$ & -0.1 & 0.1 & 0.6 & 0.5 \\
\hline Sleep quality in child & $3.1 \pm 2.1$ & $3.4 \pm 1$ & $3.3 \pm 0.5$ & $3.5 \pm 0.1$ & -0.3 & -0.2 & -0.4 & -0.3 \\
\hline Sleep quality in parent & $3.2 \pm 0.1$ & $3 \pm 0.1$ & $3.4 \pm 0.1$ & $3.6 \pm 0.2$ & 0.2 & 0.2 & -0.2 & -0.2 \\
\hline Combined & $17 \pm 3$ & $18.1 \pm 2.7$ & $17.3 \pm 2.8$ & $17.2 \pm 0.8$ & -1.1 & -0.3 & -0.2 & 0.1 \\
\hline
\end{tabular}

Table 2: Comparison of the scores before and after the intervention in the four groups.

\begin{tabular}{|c|c|c|c|}
\hline Variables & Before & After & $P$ value \\
\hline \multicolumn{4}{|c|}{ Cough frequency } \\
\hline Group I & $3.5 \pm 0.3$ & $2.7 \pm 2$ & 0.0537 \\
\hline Group II & $3.6 \pm 0.2$ & $2 \pm 1.5$ & 0.0001 \\
\hline Group III & $3.5 \pm 0.3$ & $1.8 \pm 0.8$ & 0.0001 \\
\hline Group IV & $3.7 \pm 0.1$ & $2.1 \pm 0.5$ & 0.0001 \\
\hline \multicolumn{4}{|c|}{ Cough severity } \\
\hline Group I & $3.7 \pm 0.2$ & $2.3 \pm 1.2$ & 0.0001 \\
\hline Group II & $4.5 \pm 0.2$ & $2.8 \pm 1.5$ & 0.0001 \\
\hline Group III & $3.7 \pm 0.4$ & $2 \pm 0.5$ & 0.0001 \\
\hline Group IV & $3.6 \pm 0.2$ & $1.8 \pm 1.5$ & 0.0001 \\
\hline \multicolumn{4}{|c|}{ Bothersome nature of cough } \\
\hline Group I & $3.5 \pm 0.3$ & $2.8 \pm 1.5$ & 0.0266 \\
\hline Group II & $3.6 \pm 1.2$ & $2.5 \pm 1$ & 0.001 \\
\hline Group III & $3.4 \pm 1.5$ & $1.5 \pm 0.6$ & 0.0001 \\
\hline Group IV & $2.9 \pm 0.2$ & $2.6 \pm 0.5$ & 0.0076 \\
\hline \multicolumn{4}{|c|}{ Sleep quality in child } \\
\hline Group I & $3.1 \pm 2.1$ & $2.5 \pm 1$ & 0.2033 \\
\hline Group II & $3.4 \pm 1$ & $1.3 \pm 0.5$ & 0.0001 \\
\hline Group III & $3.3 \pm 0.5$ & $1 \pm 0.8$ & 0.0001 \\
\hline Group IV & $3.5 \pm 0.1$ & $2 \pm 0.9$ & 0.0001 \\
\hline \multicolumn{4}{|c|}{ Sleep quality in parents } \\
\hline Group I & $3.2 \pm 0.1$ & $2.5 \pm 1$ & 0.001 \\
\hline Group II & $3 \pm 0.1$ & $2 \pm 0.8$ & 0.0001 \\
\hline Group III & $3.4 \pm 0.1$ & $1 \pm 0.5$ & 0.0001 \\
\hline Group IV & $3.6 \pm 0.2$ & $1.4 \pm 0.5$ & 0.0001 \\
\hline \multicolumn{4}{|l|}{ Combined } \\
\hline Group I & $17 \pm 3$ & $12.8 \pm 6.7$ & 0.006 \\
\hline Group II & $18.1 \pm 2.7$ & $10.6 \pm 5.3$ & 0.0001 \\
\hline Group III & $17.3 \pm 2.8$ & $7.3 \pm 3.2$ & 0.0001 \\
\hline Group IV & $17.2 \pm 0.8$ & $9.1 \pm 3.9$ & 0.0001 \\
\hline
\end{tabular}

Table 3: Comparison of mean differences in the scores before and after the intervention in the four groups.

\begin{tabular}{|c|c|c|c|c|c|c|c|c|c|}
\hline \multirow[b]{2}{*}{ Item } & \multicolumn{4}{|c|}{ Treatment groups } & \multirow[b]{2}{*}{ P value } & \multicolumn{4}{|c|}{ Mean difference } \\
\hline & G1 & G2 & G3 & G4 & & $\begin{array}{l}\text { G1 } \\
\text { versus } \\
\text { G2 }\end{array}$ & $\begin{array}{l}\text { G1 } \\
\text { versus } \\
\text { G3 }\end{array}$ & $\begin{array}{l}\text { G1 } \\
\text { versus } \\
\text { G4 }\end{array}$ & $\begin{array}{l}\text { G3 } \\
\text { versus } \\
\text { G4 }\end{array}$ \\
\hline Cough frequency & $0.8 \pm 1.7$ & $1.6 \pm 1.3$ & $1.7 \pm 0.5$ & $1.6 \pm 0.4$ & 0.0179 & -0.8 & -0.9 & -.8 & 0.1 \\
\hline Cough severity & $1.4 \pm 1.2$ & $1.7 \pm 0.2$ & $1.7 \pm 0.1$ & $1.8 \pm 0.1$ & 0.1191 & -0.3 & 0.3 & 0.4 & -0.1 \\
\hline $\begin{array}{l}\text { Bothersome nature of } \\
\text { cough }\end{array}$ & $0.7 \pm 1.2$ & $1.1 \pm 0.2$ & $1.9 \pm 0.9$ & $1.1 \pm 0.3$ & 0.0000 & 0.4 & -1.2 & -1.2 & 0.8 \\
\hline Sleep quality in child & $0.6 \pm 1.1$ & $2.1 \pm 0.5$ & $2.3 \pm 0.3$ & $1.5 \pm 0.8$ & 0.0000 & -1.5 & -1.7 & -0.9 & 0.8 \\
\hline Sleep quality in parents & $0.7 \pm 0.9$ & $1 \pm 0.7$ & $2.4 \pm 0.4$ & $2.2 \pm 0.3$ & 0.0000 & -0.3 & -1.7 & -1.5 & 0.2 \\
\hline Combined & $4.2 \pm 3.7$ & $7.5 \pm 2.6$ & $10 \pm 0.4$ & $8 \pm 3.4$ & 0.0000 & -3.3 & -5.8 & -3.8 & 2 \\
\hline
\end{tabular}


Table 4: Comparison of adverse effect after intervention in the four groups.

\begin{tabular}{|lllll|}
\hline \multirow{2}{*}{ Item } & Treatment groups & & \\
\hline Hangover & 0 & $10(40)$ & $8(32)$ & 0 \\
\hline Sedation & 0 & $22(88)$ & $19(76)$ & 0 \\
\hline Vomiting & $1(4)$ & $4(16)$ & $1(4)$ & 0 \\
\hline Drowsiness & 0 & $2(8)$ & $3(12)$ & 0 \\
\hline
\end{tabular}

Table 5: Time required for recovery.

\begin{tabular}{|ll|}
\hline Treatment groups & $\begin{array}{l}\text { Average days required to } \\
\text { patient for recovery }\end{array}$ \\
\hline Group I & 7.28 \\
\hline Group II & 6.50 \\
\hline Group III & 4.50 \\
\hline Group IV & 6.9 \\
\hline
\end{tabular}

\section{DISCUSSION}

In URTIs and cough no accepted therapies given. Even though it is a common condition. ${ }^{18,19}$ Nonantibiotic treatments are probably not effective for coughs. ${ }^{20}$ Many previous studies shown dextromethorphan and DPH do not relieve the nighttime symptoms of URTIs. ${ }^{21}$ Along with it OTC medications have side effects, including somnolence, restlessness, overdoses, and unexpected deaths. ${ }^{22-27} \mathrm{With}$ this data consideration cough and cold treatment with honey and ginger. In Ayurveda use of honey and ginger recommend for the treatment of cough and URTI. ${ }^{28,29}$

We consider this study, because as stated above the adverse effects of drugs causes by the dextromethorphan is more. Dextromethorphan is not preferred by pediatrician. Honey and ginger mixture is routinely given as a home remedy in children in Indian, but the scientific study was not available in literature. With available data and considering safety of honey and ginger, we consider this study.

In our study, all the four group have basic parameter similar (Table 1) and shows improvement. As shown in Table 2 parameter cough frequency, severity, bothersome nature of cough, sleep quality in children and parents significantly improved, ( $\mathrm{p}$ value $<0.05$ ). Although all four group shows significant improvement. But group three and four was shows drastic improvement (Table 3). In group three we used syp. Dextromethorphan and honey and ginger mixture, and in group 4 we use only honey and ginger mixture (Table 2 and 3 ). As we consider adverse effects in Table 4. Adverse effects were more in group 2 and group 3 as we given dextromethorphan in this group. But when we compared group 2 and 3. Adverse effects were more in group 2. Common adverse effects like hangover, sedation, vomiting and drowsiness. This is may be use of dextromethorphan alone in group 2. While in group 3 it was less due to use of honey and ginger in this group due to less use of dextromethorphan. When we see recovery days (Table 5) less in group three due to use of honey and ginger mixture along with dextromethorphan. But adverse effect is also present in group 3, may due to use of dextromethorphan while in group 4 no adverse effect seen. And in group 1 only one patient suffered from vomiting. Noticeable thing in group one and three no adverse of sedation, hangover and drowsiness in these groups. Recovery time is almost same in group 4 (only honey and ginger mixture) and group 3 (syrup dextromethorphan and honey and ginger) around 5 days, may be because of add on antibacterial property of honey and ginger. While it is more in group I and II around 7 days.

In microbiological study of honey and ginger study shows antibacterial action. ${ }^{30}$ honey and ginger is effective remedy for cough Honey has been shown to be a therapeutic option for children with acute coughs due to URTIs. ${ }^{30,31}$ Honey is a sweet and viscous nutrient, it contains free amino acids, trace elements, vitamins, flavonoids, and also have antioxidant properties, anti-inflammatory, antimicrobial, and antiviral actions, carbohydrates. . $^{14,15,27-31}$ Honey consumption induces reflexive saliva and mucus secretion in the airways, thereby relieving coughs, especially dry coughs. ${ }^{4,32}$ Another effective action given by Eccles.

There is a close anatomic relationship between the nerve fibers responsible for initiating cough and those responsible for tasting sweetness. Therefore sweet substances e.g. honey may have an antitussive effect via an interaction between these fibers. ${ }^{32}$

Extract of ginger contain phytochemical saponin, phlobatinn in, flavonoids and cardiac glycosides, alkanoids. In antibacterial test the mixture of honey and ginger ethanol extract $S$. aureus was most inhibited with the mixture of honey and ginger. ${ }^{32,33}$

In our study, the group III and four shows improvement, this may be due to addition of honey and ginger mixture. In group shows improvement along with no occurrence of adverse effects, this was due to no use of dextromethorphan along with use add on antibacterial effect of ginger and honey.

\section{Limitations}

Although honey and ginger mixture shows promising results with no adverse effects as that of dextromethorphan. But our study we include only 100 patients and duration of study was very short. For more exploration of use with advantages of honey and ginger mixture large scale study is required.

\section{CONCLUSION}

From this study we can conclude that honey and ginger has antibacterial effect. Along with it has soothing effect on irritable throat. 
Honey and ginger is easily available in market, most of the Indian population use ginger in kitchen for making of vegetables. So we can say that, honey and ginger mixture is very effective treatment of sore throat and dry cough. Along with it, no adverse effect occurrence with use of honey and ginger.

Along with use of these natural substances the irrational use of antibiotics can be stop. Patient can be benefit with lower cost of medicine.

Funding: No funding sources

Conflict of interest: None declared

Ethical approval: The study was approved by the Institutional Ethics Committee

\section{REFERENCES}

1. Rutter P. Community pharmacy: symptoms, diagnosis and treatment. 2nd ed. Churchill Livingstone. 2009.

2. Irwin RS, Baumann MH, Bolser DC, Boulet LP, Braman SS, Brightling CE, et al. Diagnosis and management of cough executive summary: ACCP evidence-based clinical practice guidelines. Chest. 2006;129:1-23.

3. Cherry DK, Burt CW, Woodwell DA. National ambulatory medical care survey: 2001 summary. Advance Data. 2003;337:1-44.

4. Vernacchio L, Kelly JP, Kaufman DW, Mitchell AA. Medication use among children $<12$ years age in united status: results from slone survey. Pediatrics. 2009; 124(2):446-54.

5. Evans H, Tuleu C, Sutcliffe A. Is honey a wellevidenced alternative to over-thecounter cough medicines? J R Soc Med. 2010;103:164-5.

6. PAGB. The Proprietary association of Great Britain annual review and report 2010. London: The Proprietary Association of Great Britain. 2010.

7. Sharfstein JM, North M, Serwint JR. Over the counter but no longer under the radar-pediatric cough and cold medications. N Engl J Med. 2007;357:2321-4.

8. MHRA. Overview: risk benefit of cough and cold medicines in children. Available at: http://www.mhra.gov.uk/home/groups/plp/documents /websiteresources/con041374.pdf. Accessed on 21 December 2020.

9. MHRA. Drug safety update 2009. Available at: http://www.mhra.gov.uk/home/groups/ plp/documents/publication/con043810.pdf. Accessed on 21 December 2020.

10. Rutter P. Community pharmacy: symptoms, diagnosis and treatment. 2nd ed. Churchill Livingstone. 2009.

11. Khare CP, Indian Medicinal Plants - An Illustrated Dictionary, Springer Science and Business Media, LLC. 2007;733-4.

12. SPI, The Siddha Pharmacopoeia of India, I Part, I Vol, Published by Central Council for Research in Ayurveda and Siddha, New Delhi, India. 2008;69-71.
13. Islam K, Rowsni AA. Antimicrobial Activity of Ginger (Zingiber Officinale) Extracts against foodborne pathogenic bacteria. Int J Sci Env Technol. 2014;3(3):867-71.

14. Sanz ML, Gonzalez M, de Lorenzo C. Carbohydrate composition and physico chemical properties of artisanal honeys from Madrid (Spain): occurrence of Echium sp honey. J Sci Food Agric. 2004;84:1577-84.

15. Mullai V, Menon T. Bactericidal activity of different types of honey against clinical and environmental isolates of pseudomonas aeruginosa. J Altern Complement Med. 2007;13:439-41.

16. Eccles R. Mechanisms of the placebo effect of sweet cough syrups. Respir Physiol Neurobiol. 2006; 152:340-8.

17. Hartnick CJ, Zurakowski D, Haver K. Validation of a pediatric cough questionnaire. Ear Nose Throat J. 2009;88(11):1213-7.

18. Paul IM, Beiler J, McMonagle A, Shaffer ML, Duda L, Berlin CM. Effect of honey dextromethorphan, and no treatment on nocturnal cough and sleep quality for coughing children and their parents. Arch Pediatr Adolesc Med. 2007;161:1140-6.

19. Ayazi P, Mahyar A, Yousef-Zanjani M, Allami A, Esmailzadehha N, Beyhaghi T. Comparison of the Effect of Two Kinds of Iranian Honey and Diphenhydramine on Nocturnal Cough and the Sleep Quality in Coughing Children and Their Parents. PLoS one. 2017;12(1):e0170277.

20. Arroll B. Non-antibiotic treatments for upperrespiratory tract infections (common cold). Respir Med. 2005;99:1477-84.

21. Finkle WD, Adams JL, Greenland S, Melmon KL. Increased risk of serious injury following an initial prescription for diphenhydramine. Ann Allergy Asthma Immunol. 2002;89:244-50.

22. Dart RC, Paul IM, Bond GR, Winston DC, Manoguerra AS, Palmer RB, et al. Pediatric fatalities associated with over the counter (nonprescription) cough and cold medications. Ann Emerg Med. 2009;53:411-7.

23. Rimsza ME, Newberry S. Unexpected infant deaths associated with use of cough and cold medications. Pediatrics. 2008;122:318-22.

24. Radovanovic D, Meier PJ, Guirguis M, Lorent JP, Kupferschmidt H. Dose-dependent toxicity of diphenhydramine overdose. Hum ExpToxicol. 2000;19:489-95.

25. Finkle WD, Adams JL, Greenland S, Melmon KL. Increased risk of serious injury following an initial prescription for diphenhydramine. Ann Allergy Asthma Immunol. 2002;89:244-50.

26. De Nesnera AP. Diphenhydramine dependence: A need for awareness. J Clin Psychiatr. 1996;57:136-7.

27. Jones J, Dougherty J, Cannon L. Diphenhydramineinduced toxic psychosis. Am $\mathrm{J}$ Emerg Med. 1986;4:369-71.

28. The Siddha Pharmacopoeia of India, I Part, I Vol, Published by Central Council for Research in Ayurveda and Siddha, New Delhi, India. 2008;69-71. 
29. Sultana S, Khan A, Safhi MM, Alhazmi HA. Cough Suppressant Herbal Drugs: A Review. Int J Pharm Sci Invent. 2016;5(5):15-8.

30. Omoya FO, Akharaiyi FC. Mixture of Honey and Ginger Extract for Antibacterial Assessment on Some Clinical Isolates. Int Res J Pharm. 2012;2(5):127-32.

31. Paul IM. Therapeutic Options for Acute Cough Due to Upper Respiratory Infections in Children. Lung. 2012;190:41-4.

32. Sultana S, Khan A, Safhi MM, Alhazmi HA. Cough Suppressant Herbal Drugs: A Review. Int J Pharm Sci Invent. 2016;5(5):15-28.
33. Townsend EA, Siviski ME, Zhang Y, Xu C, Hoonjan B, Emala CW. Effects of Ginger and Its Constituents on Airway Smooth Muscle Relaxation and Calcium Regulation. Am J Resp Cell Mol Biol. 2013;48:15763.

Cite this article as: Jaybhaye DL, Chandra S, Johar S, Nagre AS. Comparative effect of mixture of ginger and honey with dextromethorphan in dry cough in children. Int J Basic Clin Pharmacol 2021;10:545-51. 